University of Nebraska - Lincoln

DigitalCommons@University of Nebraska - Lincoln

\title{
Seeding Rates for Establishing Big Bluestem and Switchgrass with Preemergence Atrazine Applications
}

Kenneth P. Vogel

University of Nebraska-Lincoln, kvogel1@unl.edu

Follow this and additional works at: https://digitalcommons.unl.edu/usdaarsfacpub

Vogel, Kenneth P., "Seeding Rates for Establishing Big Bluestem and Switchgrass with Preemergence Atrazine Applications" (1987). Publications from USDA-ARS / UNL Faculty. 1887.

https://digitalcommons.unl.edu/usdaarsfacpub/1887

This Article is brought to you for free and open access by the U.S. Department of Agriculture: Agricultural Research Service, Lincoln, Nebraska at DigitalCommons@University of Nebraska - Lincoln. It has been accepted for inclusion in Publications from USDA-ARS / UNL Faculty by an authorized administrator of DigitalCommons@University of Nebraska - Lincoln. 


\title{
Seeding Rates for Establishing Big Bluestem and Switchgrass with Preemergence Atrazine Applications ${ }^{1}$
}

\author{
Kenneth P. Vogel ${ }^{2}$
}

\begin{abstract}
The purpose of this study was to determine seeding rates for establishing switchgrass (Panicum virgatum $L$.) and debearded big bluestem (Andropogon gerardii Vitman) when atrazine [6-chloro- $N$ ethyl- $N$-(1-methylethyl)-1,3,5-triazine-2,4-diamine] is used as a preemergence herbicide. The high seed cost of these grasses makes it uneconomical to use higher seeding rates than necessary. The study was conducted on four eastern Nebraska sites during the period 1981 to 1985 . The experimental design was a randomized complete block with six replications. Treatments were grasses (big bluestem and switchgrass) and seeding rates $[107,215,325$, and 430 pure live seeds (PLS) $\mathrm{m}^{-2}$ ] in a factorial arrangement. Plots were seeded in late spring with a plot seeder with double disk openers on a clean, firm seedbed, and broadcast sprayed with 2.2 or $3.0 \mathrm{~kg} \mathrm{ha}^{-1}$ atrazine the day after seeding. Stands and forage yields were measured the first (Year 1) and second year (Year 2) following establishment. The 107 PLS $\mathrm{m}^{-2}$ seeding rate resulted in thinner, but still acceptable, stands (10-20 plants $\mathrm{m}^{-2}$ ) than the higher seeding rates in Year 1 and at two of the sites in Year 2. The stands from the higher rates, in general, did not differ within a site and were good to excellent (>20 plants $\mathrm{m}^{-2}$ ). The lowest seeding rate produced lower forage yields than the other rates in Year 1 , but these differences were significant at only one site. There were no differences for Year 1 yield for the other rates or for Year 2 yields for all rates.
\end{abstract}

Additional index words: Panicum virgatum L., Andropogon gerardii Vitman, Forage yields, Establishment, Prairie grasses, Warm-season grasses.

CEeDING rates for switchgrass (Panicum virgatum L.) and big bluestem (Andropogon gerardii Vitman) were developed primarily by empirical methods. Cornelius (1944) reported that 400 pure live seeds (PLS) $\mathrm{m}^{-2}$ provided ample seeds for establishment of a warmseason grass mixture and that 20 established plants $\mathrm{m}^{-2}$ would give a stand similar to that of native prairie in 2 yr. Launchbaugh (1966), in a stand establishment survey of over 3000 grass plantings in the Great Plains, classified plantings with 10 or more seedling $\mathrm{m}^{-2}$ as good stands.

In a designed study at Hays, KS, Launchbaugh and

'A contribution of the USDA-ARS and the Univ. of NebraskaLincoln. Published as Paper no. 8066, Journal Series, Nebraska Agric. Res. Div. Received 19 May 1986.

${ }^{2}$ Supervisory research geneticist, USDA-ARS, and adjunct professor, Dep. of Agronomy, Univ. of Nebraska, Lincoln, NE 68583.

Published in Agron. J. 79:509-512 (1987).
Owensby (1970) determined that establishment-year stands of 10 to 20 plants $\mathrm{m}^{-2}$ of native grasses including big bluestem and switchgrass were generally ready to be grazed the following year. Seeding rates of 200 to 300 PLS m$~^{-2}$ were needed to achieve these stands with big bluestem, but rates greater than 400 PLS $\mathrm{m}^{-2}$ were needed for switchgrass. In a set of designed studies in eastern Nebraska, Sall (1963) determined that seeding rates in excess of 400 PLS m$~^{-2}$ were not necessary for establishing switchgrass and indiangrass [Sorghastrum nutans (L.) Nash]. He also determined that mid- to late-spring dates of seeding are most suitable for these grasses in eastern Nebraska. Seeding rate recommendations of 200 to $400 \mathrm{PLS} \mathrm{m}^{-2}$ for switchgrass and big bluestem are based on these reports, studies, and other unpublished observations.

Two recent developments necessitated the re-evaluation of these seeding recommendations. Martin et al. (1982) documented that switchgrass and big bluestem have seedling tolerance to preemergence applications of atrazine [6-chloro- $N$-ethyl- $N^{\prime}$-(1-methylethyl)-1,3,5-triazine-2,4-diamine] and that preemergence applications of this herbicide greatly improved establishment of these grasses by reducing weed competition. The seed unit of big bluestem, which includes the fertile spikelet, the joint of the raceme, and the stalk of the sterile spikelet, has an awn and dense pubescence, which makes the seed extremely chaffy (Wheeler and Hill, 1957). Brown et al. (1981) developed a method of debearding (removing the chaffy awns and other seed appendages) big bluestem, which greatly increases its bulk density and its ability to flow through planting equipment. Previous seeding recommendations were based on seedings with chaffy seed. In contrast to big bluestem, switchgrass has a smooth seed that flows easily through planters. The purpose of this study was to determine seeding rates for switchgrass and debearded big bluestem when atrazine is used as a preemergence herbicide.

Recently, Vassey et al. (1985) studied the optimum rate and date for seeding switchgrass in central Iowa when atrazine is used as a preemergence herbicide. They used seeding rates of 3.4, 6.7, 10.1, 13.4, and $16.8 \mathrm{~kg} \mathrm{ha}^{-1}$ for 'Cave-in-Rock' switchgrass in early, 
mid-, and late-spring plantings. Seed weight values were not reported. If the mean of published seed weight values of 859 seeds $\mathrm{g}^{-1}$ (Wheeler and Hill, 1957) and 814 seeds $\mathrm{g}^{-1}$ (Martin and Leonard, 1967) is used to convert these values to PLS per square meter, the planting rates are equivalent to $284,560,844,1120$, and 1404 PLS m$~^{-2}$, respectively. Their conclusions were that switchgrass should be seeded during mid-to-late April or early May and that when atrazine is used for weed control, a seeding rate of $3.4 \mathrm{~kg} \mathrm{ha}^{-1}$ PLS (284 PLS m$~^{-2}$ ) is adequate to obtain productive stands. They suggested that higher seeding rates would be needed only if an adequate planter was not available or if severe stress conditions were anticipated. Seed rates lower than those tested by Vassey et al. (1985) were included in this study because the high seed cost of these grasses makes it uneconomical to use higher seeding rates than necessary.

\section{MATERIALS AND METHODS}

Seeding rate studies were conducted at the University of Nebraska Agricultural Research and Development Center at Mead, NE (35 km west of Omaha, NE), in 1981, 1982, and 1983, and on the Leonard Christian farm in Pawnee County, NE (120 km south of Omaha, NE), in 1981. Seedings at Mead were made in 1981 and 1983 on a Sharpsburg silty clay loam (Typic Argiudoll) and in 1982 on a Butler silty clay loam (Abruptic Argiaquoll). The Pawnee County seeding was made on a Pawnee clay loam (Aquic Argiudoll).

Each seeding rate experiment was a randomized complete block with six replicates. Treatments were grasses, big bluestem and switchgrass, and seeding rates, 107, 215, 323, and 430 PLS $\mathrm{m}^{-2}\left(10,20,30\right.$, and $\left.40 \mathrm{PLS} \mathrm{ft.}^{-2}\right)$, in a factorial arrangement. Plots were seeded using the plot drill described by Vogel (1978). The plot size was 1.2 by $4.3 \mathrm{~m}$ long. The quantity of seed necessary to seed a $1.2-$ by $6-\mathrm{m}\left(7.4-\mathrm{m}^{2}\right)$ plot was placed in the drill's cone, and the cone was set to make one revolution in $6 \mathrm{~m}$. Seeding began in the middle of an alley, and the drill was empty and cleaned in the middle of the next alley; the process was then repeated. After emergence, plots were uniformily trimmed to $4.3 \mathrm{~m}$ in length. Germination percentages and 100-seed weights of the seed lots used to determine PLS are listed in Table 1.

Big bluestem seed was debearded using a small laboratory debearder that duplicates the results of the debearder described by Brown et al. (1981). The plots -were seeded into clean, firm seedbeds to a depth of $1 \mathrm{~cm}$. The seeding dates were 3 June (Mead, 1981), 29 May (Pawnee, 1981), 4 June (Mead, 1982), and 24 May (Mead, 1983). Atrazine was broadcast on plots the day after seeding at a rate of $2.2 \mathrm{~kg}$ a.i. ha ${ }^{-1}$, except at Mead in 1981 when a $3.0 \mathrm{~kg} \mathrm{ha}^{-1}$ rate was used. The experiments did not receive additional herbicide treatments the establishment year, except for Mead

Table 1. Seed lots used to seed the rate of seeding studies in eastern Nebraska in 1981, 1982, and 1983.

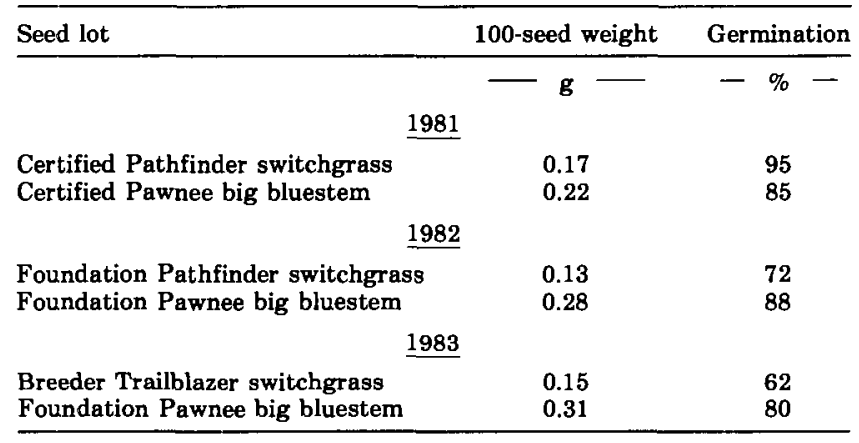

in 1981 where the study area was mowed on $30 \mathrm{July}$ and sprayed with $1.1 \mathrm{~kg} \mathrm{ha}^{-1}$ 2,4-D [(2,4-dichlorophenoxy)acetic acid] on 12 August. The Pawnee and Mead 1983 experirnents were also mowed or hayed in late summer of the establishment year.

In the first (Year 1) and second year (Year 2) following establishment, the studies were burned or mowed in early spring before spring greenup and fertilized with $112 \mathrm{~kg} \mathrm{ha}^{-1}$ $\mathrm{N}$ at Mead and with $56 \mathrm{~kg} \mathrm{ha}^{-1}$ at Pawnee. Since stands for all rates were greater than 10 plants $\mathrm{m}^{-2}$, atrazine $(2.2 \mathrm{~kg}$ $\left.\mathrm{ha}^{-1}\right)$ or an atrazine and alach].or [2-chloro- $N$-(2,6-diethylphenyl)- $N$-(methoxymethyl) acetamide] herbicide mixture was applied in May in the post-establishment years to eliminate the need for hand weeding or hand separation of weeds and forage during harvest and to prevent self-seeding of the plots. In 1982, $2.2 \mathrm{~kg} \mathrm{ha}^{-1}$ atrazine plus $1.1 \mathrm{~kg} \mathrm{ha}^{-1}$ 2,4-D were applied to the 1981 Mead and Pawnee experiments. In 1983 and $1984,1.1 \mathrm{~kg} \mathrm{ha}^{-1}$ atrazine plus $2.2 \mathrm{~kg} \mathrm{ha}^{-1}$ alachlor were applied to all previously established studies.

Frequency-of-occurrence measurements were taken after spring greenup in the first and second year following establishment by placing a metal grid containing 25 squares over the center five rows of each plot. Each square was $15 \mathrm{~cm}$ in length. The number of squares containing one or more seeded grass plants was counted and the process was repeated in another section of the same plot. The frequency of occurrence is reported as a stand percentage.

Forage yields were determined by harvesting either a 0.6m-wide swath down the length of each plot with a sickle bar mower, or a $0.9-\mathrm{m}$-wide swath with a flail-type plot harvester. Cutting height was $5 \mathrm{~cm}$ with the mower and $10 \mathrm{~cm}$ with the flail harvester. Grasses were harvested after heading, except in 1985 when they were harvested in the late boot stage. Forage samples were dried in a $50^{\circ} \mathrm{C}$ oven to determine dry matter content. All yields are expressed as megagrams per hectare of dry matter.

Each seeding experiment was analyzed separately using ANOVA procedures. Barlett's test (Steel and Torrie, 1960) was used to test for homogeneity of the error variances of the individual experiments. Although the error variances were not homogeneous because of large seeding $X$ site (year-location) effects, an over-site analysis was conducted because the results of the individual experiments were essentially similar. The over-environments analysis was used to partition seeding rate effects into linear, quadratic, and cubic effects, using orthogonal contrasts (Steel and Torrie, 1950).

Stands and productivity the first and second year following establishment provide the essential measures of the success of a new seeding for perennials such as big bluestem and switchgrass. Therefore, seeding year stands and forage yields were not determined in this study. Stands and yields the first year following establishment were not measured at Pawnee County. Second-year stands were not measured the second year following establishment for the 1982 Mead seeding.

\section{RESULTS AND DISCUSSION}

The effects of seeding rate on stands were similar for each of the sites, although Bartlett's test indicated that error variances were not homogeneous (Table 2). The size of the means did vary among sites. Seeding rate had a significant effect on Year 1 stand for all plantings for which Year 1 stands were measured (Table 2). The $107 \mathrm{PLS} \mathrm{m}^{-2}$ rate produced lower Year 1 stands than the other rates (Table 3). Year 1 stands did not differ among the other rates except for the Mead 1981 planting, where the highest seeding rate gave superior stands for big bluestem, resulting in the significant grass $\times$ seeding rate interaction effect for the Year 1 stand. The lowest seeding rate also produced the lowest Year 2 stands for the Mead 1981 and 
Table 2. Analyses of variance for big bluestem and switchgrass stands and forage yields in the first year (Year 1) and the second year (Year 2) following establishment for four sites in eastern Nebraska.

\begin{tabular}{|c|c|c|c|c|c|}
\hline \multirow[b]{3}{*}{ Source } & \multirow[b]{3}{*}{ df } & \multicolumn{4}{|c|}{ Mean squares } \\
\hline & & \multicolumn{2}{|c|}{ Year 1} & \multicolumn{2}{|c|}{ Year 2} \\
\hline & & Stand & Yield & Stand & Yield \\
\hline & & $\%$ & $\mathrm{Mg} \mathrm{ha}^{-1}$ & $\%$ & Mg ha ${ }^{-1}$ \\
\hline & & \multicolumn{4}{|c|}{ Mead 1981} \\
\hline $\begin{array}{l}\text { Grass } \\
\text { Seeding rate } \\
\text { Rep } \\
\text { Grass } \times \text { seeding rate } \\
\text { Error }\end{array}$ & $\begin{array}{r}1 \\
3 \\
5 \\
3 \\
27\end{array}$ & $\begin{array}{c}7 \\
931^{* *} \\
79 \\
425^{*} \\
136\end{array}$ & $\begin{array}{l}26.50^{* *} \\
4.72 \\
7.83 \\
2.71 \\
1.91\end{array}$ & $\begin{array}{c}3000^{* *} \\
567^{* *} \\
101 \\
94 \\
78\end{array}$ & $\begin{array}{l}55.22^{* *} \\
3.06 \\
7.18 \\
3.61 \\
3.76\end{array}$ \\
\hline & & \multicolumn{4}{|c|}{ Mead 1982} \\
\hline $\begin{array}{l}\text { Grass } \\
\text { Seeding rate } \\
\text { Rep } \\
\text { Grass } \times \text { seeding rate } \\
\text { Error }\end{array}$ & $\begin{array}{r}1 \\
3 \\
5 \\
3 \\
35\end{array}$ & $\begin{array}{l}936^{*} \\
1853^{* *} \\
703^{*} \\
416 \\
225\end{array}$ & $\begin{array}{l}23.40^{*} \\
24.10^{* *} \\
14.51^{* *} \\
9.54 \\
3.92\end{array}$ & & $\begin{array}{l}17.92^{*} \\
1.86 \\
2.96 \\
5.02 \\
3.21\end{array}$ \\
\hline & & \multicolumn{4}{|c|}{ Mead 1983} \\
\hline $\begin{array}{l}\text { Grass } \\
\text { Seeding rate } \\
\text { Rep } \\
\text { Grass } \times \text { seeding rate } \\
\text { Error }\end{array}$ & $\begin{array}{r}1 \\
3 \\
5 \\
3 \\
35\end{array}$ & $\begin{array}{l}397^{* *} \\
669^{* *} \\
113 \\
122 \\
78\end{array}$ & $\begin{array}{c}115.36^{* *} \\
2.26 \\
8.33^{* *} \\
1.61 \\
1.85\end{array}$ & $\begin{array}{l}114 \\
857^{* *} \\
45 \\
82 \\
38\end{array}$ & $\begin{array}{l}32.78^{* *} \\
1.76 \\
0.55 \\
1.40 \\
0.70\end{array}$ \\
\hline & & \multicolumn{4}{|c|}{ Pawnee 1981} \\
\hline $\begin{array}{l}\text { Grass } \\
\text { Seeding rate } \\
\text { Rep } \\
\text { Grass } \times \text { seeding rate } \\
\text { Error }\end{array}$ & $\begin{array}{r}1 \\
3 \\
5 \\
3 \\
35\end{array}$ & & & $\begin{array}{r}2 \\
295 \\
456 \\
109 \\
254\end{array}$ & $\begin{array}{l}57.58^{* *} \\
1.76 \\
2.51 \\
3.61 \\
1.46\end{array}$ \\
\hline Bartlett's test $\left(\chi^{x}\right)$ & & $9.11^{* *}$ & $6.21^{*}$ & $30.98^{* *}$ & $9.23^{*}$ \\
\hline
\end{tabular}

*,** Indicates significance at the 0.05 and 0.01 levels of probability, respectively.

1983 plantings but produced stands equivalent to the other rates for the Pawnee planting. There were no differences in Year 2 stands for the other seeding rates. The grass $X$ seeding rate interaction effect was significant only for Year 1 stands for the Mead 1981 planting, indicating that stands of both grasses respond similarily to changes in seeding rates (Table 2).
Table 3. Mean stands and forage yields for big bluestem (BB) and switchgrass (SW) in the first year (Year 1) and second year (Year 2) following establishment at four seeding rates in eastern Nebraska.

\begin{tabular}{|c|c|c|c|c|c|c|c|c|}
\hline \multirow[b]{3}{*}{ Seeding rate } & \multicolumn{4}{|c|}{ Year 1} & \multicolumn{4}{|c|}{ Year 2} \\
\hline & \multicolumn{2}{|c|}{ Stand } & \multicolumn{2}{|c|}{ Yield } & \multicolumn{2}{|c|}{ Stand } & \multicolumn{2}{|c|}{ Yield } \\
\hline & BB & SW & BB & sw & BB & sw & BB & Sw \\
\hline PLS $\mathrm{m}^{-2}$ & \multicolumn{2}{|c|}{$-\%-$} & \multicolumn{2}{|c|}{$\mathrm{Mg} \mathrm{ha}^{-1}$} & \multicolumn{2}{|c|}{$-\%$} & \multicolumn{2}{|c|}{$\mathbf{M g ~ h \mathbf { a } ^ { - 1 }}$} \\
\hline Mead 1981 & & & & & & & & \\
\hline $\begin{array}{c}107 \\
215 \\
323 \\
430 \\
\text { LSD } 0.05 \dagger\end{array}$ & $\begin{array}{l}32 \\
42 \\
34 \\
62 \\
14\end{array}$ & $\begin{array}{l}27 \\
40 \\
50 \\
48 \\
14\end{array}$ & $\begin{array}{l}6.5 \\
8.7 \\
6.3 \\
5.8 \\
\text { NS }\end{array}$ & $\begin{array}{l}7.0 \\
9.0 \\
8.7 \\
9.0 \\
\text { NS }\end{array}$ & $\begin{array}{l}56 \\
75 \\
68 \\
77 \\
10\end{array}$ & $\begin{array}{l}74 \\
85 \\
93 \\
92 \\
10\end{array}$ & $\begin{array}{l}12.1 \\
10.8 \\
10.1 \\
10.8 \\
\text { NS }\end{array}$ & $\begin{array}{l}13.7 \\
14.6 \\
13.4 \\
12.3 \\
\text { NS }\end{array}$ \\
\hline \multicolumn{9}{|l|}{ Mead 1982} \\
\hline $\begin{array}{c}107 \\
215 \\
323 \\
430 \\
S D 0\end{array}$ & $\begin{array}{l}57 \\
70 \\
72 \\
82 \\
16\end{array}$ & $\begin{array}{l}38 \\
69 \\
76 \\
64 \\
16\end{array}$ & $\begin{array}{l}7.6 \\
9.0 \\
7.8 \\
9.2 \\
2.2\end{array}$ & $\begin{array}{r}6.5 \\
11.4 \\
10.5 \\
10.8 \\
2.2\end{array}$ & & & $\begin{array}{r}10.1 \\
10.1 \\
9.4 \\
10.8 \\
\text { NS }\end{array}$ & $\begin{array}{r}7.6 \\
9.2 \\
9.9 \\
8.7 \\
\text { NS }\end{array}$ \\
\hline
\end{tabular}

Mead 1983

$\begin{array}{ccccccccc}107 & 68 & 81 & 4.9 & 9.0 & 68 & 77 & 6.3 & 8.5 \\ 215 & 86 & 88 & 5.6 & 9.2 & 88 & 87 & 6.7 & 8.7 \\ 323 & 90 & 89 & 6.5 & 9.0 & 90 & 88 & 7.0 & 8.1 \\ 430 & 87 & 94 & 6.7 & 9.2 & 88 & 94 & 7.6 & 8.7 \\ \text { LSD 0.05† } & 10 & 10 & \text { NS } & \text { NS } & 7 & 7 & \text { NS } & \text { NS }\end{array}$

Pawnee 1981

107
215
325
430
LSD $0.05 \dagger$

$\begin{array}{llll}69 & \mathbf{7 3} & 3.6 & \mathbf{4 . 7} \\ \mathbf{6 1} & \mathbf{6 5} & 3.8 & \mathbf{5 . 8} \\ \mathbf{7 4} & \mathbf{6 5} & 3.1 & \mathbf{6 . 7} \\ \mathbf{6 1} & \mathbf{6 0} & \mathbf{4 . 0} & \mathbf{5 . 8} \\ \text { NS } & \text { NS } & \text { NS } & \text { NS }\end{array}$

Overall

\begin{tabular}{ccccccccc}
107 & 53 & $\mathbf{5 3}$ & $\mathbf{6 . 3}$ & $\mathbf{7 . 6}$ & $\mathbf{6 5}$ & $\mathbf{7 5}$ & $\mathbf{7 . 6}$ & $\mathbf{7 . 8}$ \\
215 & 69 & 66 & 7.6 & $\mathbf{9 . 9}$ & $\mathbf{7 4}$ & $\mathbf{7 9}$ & $\mathbf{7 . 6}$ & 9.6 \\
325 & 65 & 71 & 7.0 & $\mathbf{9 . 4}$ & $\mathbf{7 7}$ & $\mathbf{8 2}$ & $\mathbf{7 . 4}$ & $\mathbf{9 . 6}$ \\
$\mathbf{4 3 0}$ & $\mathbf{7 8}$ & $\mathbf{7 0}$ & $\mathbf{7 . 2}$ & $\mathbf{9 . 6}$ & $\mathbf{7 5}$ & $\mathbf{8 2}$ & 8.1 & 8.7 \\
LSD 0.05† & 11 & 11 & NS & NS & NS & NS & NS & NS \\
\hline
\end{tabular}

$\dagger$ The LSD 0.05 for seeding rate within a grass. NS indicates that the $F$ test for seeding rate was not significant at $P \leq 0.05$.

In the over-site analysis, the linear effect of seeding rate on Year 1 stands was significant for big bluestem and switchgrass (Table 4). The analysis was conducted

Table 4. Analyses of variance over sites for big bluestem (BB) and switchgrass (SW) stands and forage yield in the first year (Year 1) and the second year (Year 2) following establishment in eastern Nebraska, using orthogonal contrasts for seeding rate.

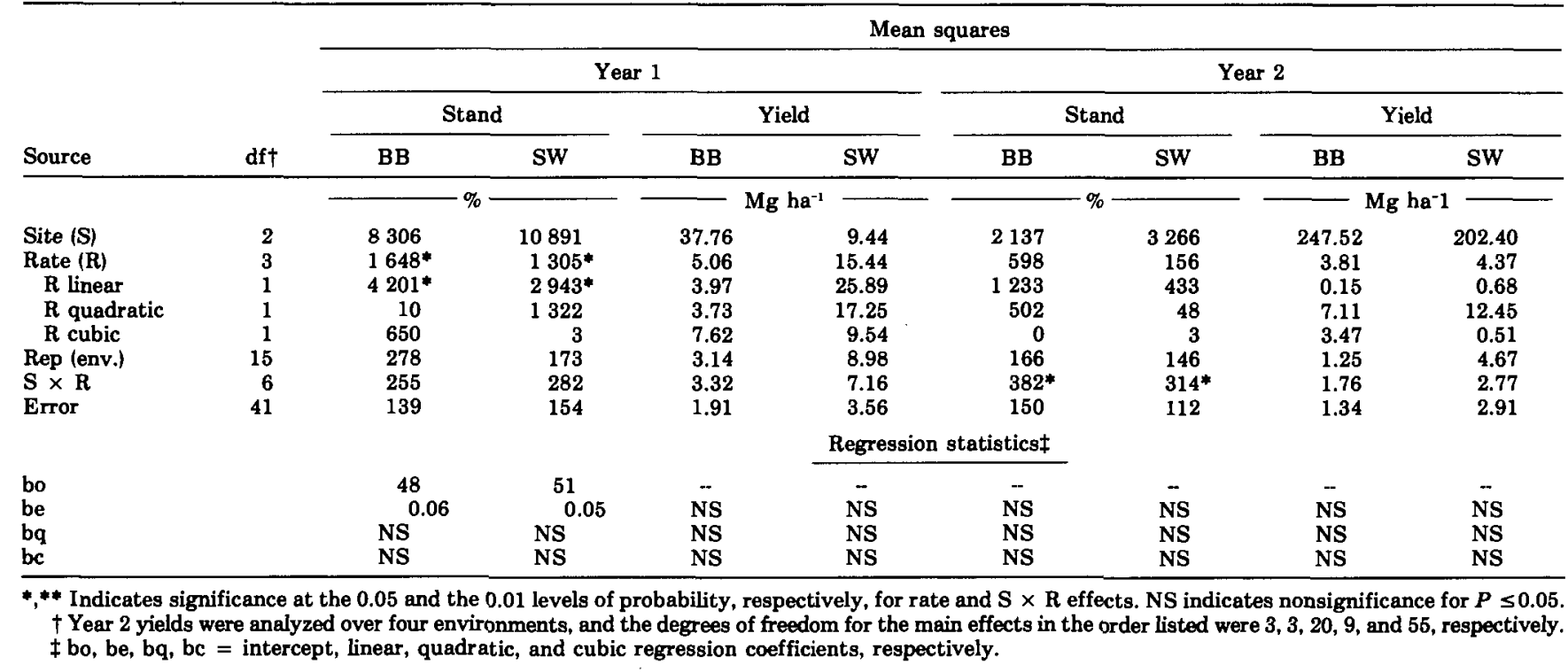


Table 5. Precipitation during the establishment-year growing season for four seeding year sites in eastern Nebraska. $\dagger$

\begin{tabular}{lrrrrrr}
\hline & \multicolumn{6}{c}{ Precipitation } \\
\cline { 2 - 7 } Sites & April & May & June & July & August & September \\
\cline { 2 - 7 } & & & & & & \\
Mead-1981 & 51 & 110 & 40 & 84 & 191 & 59 \\
Pawnee-1981 & 29 & 93 & 90 & 143 & 136 & 119 \\
Mead-1982 & 46 & 224 & 137 & 81 & 193 & 117 \\
Mead-1983 & 22 & 124 & 179 & 20 & 62 & 72 \\
\hline
\end{tabular}

† National Oceanic and Atmospheric Administration, 1981-1983.

for each grass because the grass effect was significant in the single-site analysis for most variables. When analyzed over sites, seeding rate effects were not significant for Year 2 stands. The linear effect of seeding rate on first year stands can be attributed to the differences between the 107 PLS m$~_{-2}$ and the higher seeding rates. The coefficient of determination $\left(r^{2}\right)$ for the linear model was 0.84 and 0.83 , for big bluestem and switchgrass, respectively. Quadradic and cubic effects were not significant for Year 1 or Year 2 stands.

The results were similar for each of the four sites, even though precipitation varied considerably among sites during the establishment year, particularly during the critical first 30 days following seeding (Table 5). The lowest precipitation following seeding was at Mead in 1981 , where the first rainfall $(25 \mathrm{~mm})$ occurred 21 days after planting, and only an additional $15 \mathrm{~mm}$ of rain fell before 1 July. For the other plantings, adequate rainfall occurred within 2 weeks of planting. The less favorable rainfall conditions at Mead in 1981 resulted in lower Year 1 stands than in the other environments. Year 2 stands for the Mead 1981 planting were similar to the Year 2 stands for the other sites because of tillering of the established plants.

Even though Year 1 stands for the Mead 1981 seedling were lower than for the other sites, all stands including the stands produced from the 107 PLS m-2 rate would have been classed as acceptable stands using Launchbaugh's and Owensby's criteria (1970) of 10 to 20 plants $\mathrm{m}^{-2}$. Multiplying stands (Table 3 ) by 0.4 provides a conservative estimate of plants per square meter since it assumes only one plant was found in each $15-\mathrm{cm}$ square when, in fact, each grid square usually contained several plants.

The lowest seeding rate usually produced the lowest Year 1 forage yields, but these differences were significantly different only for the Mead 1982 planting (Tables 2,3). By the second year following establishment, forage yields were similar for all seeding rates (Table 3). Switchgrass produced higher forage yields than big bluestem for all harvests, except for Year 2 yields for the Mead 1982 planting. When analyzed over sites, seeding rate effects were not significant for Year
1 and Year 2 forage yields (Table 4). Forage yield did not respond to the seeding rates evaluated because adequate stands were achieved by all seeding rates. These results support Launchbaugh's and Owensby's conclusion (1970) that initial stands of 10 to 20 plants $\mathrm{m}^{-2}$ are adequate to obtain productive stands of big bluestem or switchgrass.

Weed control generally was adequate for each of the plantings during the establishment year, except for 1981 at Mead when the effectiveness of atrazine was reduced by the limited rainfall in the 30 days following application. A single application of 2,4-D combined with mowing provided adequate additional weed control.

In summary, when atrazine is used as a preemergence herbicide for establishing switchgrass and big bluestem, seeding rates greater than 200 PLS $\mathrm{m}^{-2}$ are not necessary to obtain adequate stands if seeds are planted in a firm seedbed at the proper depth in the spring. Seeding rates of $100 \mathrm{PLS} \mathrm{m} \mathrm{m}^{-2}$ may be sufficient in many years, particularly if the plantings are being used to establish conservation rather than pasture grasslands; i.e., two or more years of non-use is planned, which will allow stands to improve. Since germination and 100-seed weight vary between seed lots for these grasses (Table 1), it is important to determine seeding rate based on the 100-seed weight and germination percentage of the seed lots being planted rather than using average planting rate recommendations.

\section{REFERENCES}

Brown, R.R., J. Henry, and W. Crowder. 1981. Improved processing for high quality seed of big bluestem, Andropogon gerardii, and yellow indiangrass, Sorghastrum nutans. p. 272-274. In J.A. Simith and V.W. Hays (ed.) Proc. 14th Int. Grassl. Congr., Lexington, KY. 15-24 June 1981. Westview Press, Boulder, CO.

Cornelius, D.R. 1944. Revegetation in the tallgrass praire region. J. Am. Soc. Agron. 36:393-400.

Launchbaugh, J.L. 1966. A stand establishment survey of grass plantings in the Great Plains. Nebraska Agric. Exp. Stn. Great Plains Council Publ. 23.

, and C.E. Owensby. 1970. Seeding rate and first-year stand relationships for six native grasses. J. Range Manage. 23:414-417.

Martin, A.R., R.S. Moomaw, and K.P. Vogel. 1982. Warm-season grass establishment with atrazine. Agron. J. 74:916-920.

Martin, J.H., and W.H. Leonard. 1967. Principles of field crop production. McMillian Co., New York.

National Oceanic and Atmospheric Administration. 1981-1983. Climatological data annual summaries for Nebraska. 1981, 1982, and 1983. Ashville, NC.

Sall, R.G. 1963. Stand establishment of certain perennial grasses in relation to rate and date of planting. M.S. thesis. Univ, of Nebraska, Lincoln.

Steel, R.G.D., and J.H. Torrie. 1960. Principles and procedures of statistics. McGraw-Hill Book Co., Inc., New York.

Vassey, T.L., J.R. George, and R.E. Mullen. 1985. Early-, mid-, and late-spring establishment of switchgrass at several seeding rates. Agron. J. 77:253-257.

Vogel, K.P. 1978. A simple method of converting rangeland drills to experimental plot seeders. J. Range Manage. 31:235-237.

Wheeler, W.A., and D.D. Hill. 1957. Grassland seeds. D. Van Nostrand, Inc., Princeton, NJ. 